\title{
A MULDIMENSIONAL APPROACH OF THE RELATIONSHIP BETWEEN TELEWORKING AND EMPLOYEES WELL-BEING - ROMANIA DURING THE PANDEMIC GENERATED BY THE SARS-COV-2 VIRUS
}

\author{
Dumitru Miron ${ }^{1}$, Monica Aureliana Petcu², Maria Iulia David-Sobolevschi ${ }^{\text {** }}$ \\ and Radu Cezar Cojocariu ${ }^{4}$ \\ 1)23)4) Bucharest University of Economic Studies, Romania
}

Please cite this article as:

Miron, D., Petcu, M.A., David-Sobolevschi, M.I. and Cojocariu, R.C., 2021. A Muldimensional Approach of the Relationship Between Teleworking and Employees WellBeing - Romania During the Pandemic Generated by the SarsCov-2 Virus. Amfiteatru Economic, 23(58), pp. 586-600.

DOI: $10.24818 / \mathrm{EA} / 2021 / 58 / 586$
Article History

Received: 29 March 2021

Revised: 22 May 2021

Accepted: 10 June 2021

\begin{abstract}
The inclusion of the issue of well-being in the social space, by contextualizing the process in functions of reconfiguring working conditions is of significant interest for both employees and employers in win-win approach. The dynamical systems produce chaotic behavior amplified by specific nonlinear feedback mechanisms and irreversible irregularities. The pandemic generated by SARS-CoV-2 virus has determined the extension of the use of telework and the issue of the dichotomy related potential benefits/ disadvantages associated with it. The anomie of the society with multiple dysfunctions is potentiated by the individual anomie induced by anti-pandemic measures. The purpose of this study is to analyze the impact of telework on employee well-being, from the perspective of the theory of social production function, considering seven areas of evaluation, assessed on the basis of specific items. In order to collect the subjectively perceived information, we developed an opinion questionnaire. The information was processed using correlation analysis and regression analysis. We noticed there are some differences in the perception of well-being depending on the workplace and gender. There is a positive relationship between professional development and competences, job satisfaction, work-life balance, organizational climate and well-being, and a negative relationship between the emotional dimension, commitment, autonomy and well-being in the case of the telework.
\end{abstract}

Keywords: telework, well-being, autonomy, commitment, job satisfaction, emotional dimension, the function of social production.

JEL Classification: J01, J50

* Corresponding author: Maria Iulia David - Sobolevschi - e-mail: iulia.david@kgaudit.ro

Authors' ORCID:

Dumitru Miron: orcid.org/0000-0003-0606-6329

Monica Aureliana Petcu: orcid.org/0000-0003-0725-5770

Maria Iulia David - Sobolevschi: orcid.org/0000-0003-2701-5563

Radu Cezar Cojocariu: orcid.org/0000-0001-7605-8186 


\section{Introduction}

The profound systemic disorders induced by the gaps between technological development, capital mobility and societal structures impose responses of humanity to a globalized challenge and paradigmatic reconstruction. It can be affirmed that all components of the environment undergo structural transformations, achieving in an extremely short time quantitative accumulations that produce major qualitative changes in society against the background of antagonisms between inertia and dynamism, remanence and resistance characteristic of systems with routine procedures, strongly anchored. Naisbit (1980: 60) stated that the road from minimum resistance to the improvement of previous technologies has been taken and we are in the stage in which new directions and uses are being born. In this complex and particularly dynamic process, the individual is the origin of the transformations and, at the same time, the one forced to adapt quickly and effectively to a profoundly different way of life.

Structural adaptation to the digital economy involves the interaction between social and technological factors from the perspective of the work environment, the characteristics of the workplace being significantly changed. Globalization, organizational restructuring, the expansion of the use of information technology in the workplace, the flexibility of the work schedule have determined a new design of work. The increasing use of telework, amplified by the restrictive conditions imposed by the health crisis generated by SARS-CoV-2 virus, has significant effects at the individual, corporate and societal level.

The debates regarding the concept of telework, the assertion about the impact of telework on the well-being of employees reveal the importance and complexity of the issue. The European Commission, specialists such as Korte, Wynne and Wynne (1996) established as defining elements of telework: the existence of an employment contract; organization of work totally or partially outside the location of the employer or a client, at the employee's home or in the form of mobile work; use of information technology; communication with the organization. Telework, through its requirements, is a key element in the European Commission's employment policy, stimulating: employability - telework involves computer skills and the ability to work independently, important aspects in assessing employability; entrepreneurship - micro and new enterprises use telework to an increasing extent; adaptability - through the ability of employees to use information and communication technology creatively and to work in networks, teleworking ensures the flexibility and adaptability of entities; equal opportunities - teleworking ensures a higher degree of employment of women and people with disabilities.

The pandemic put people in the situation of organizing themselves in a telework, which implies seclusion, self-government, with particular consequences up to the individual level. The controversies over the effectiveness of telework are not surprising due to the associated complexity, as well as to the dichotomy of benefits/disadvantages potentially associated with it. The way in which companies perceive and develop this method of work, the multiple implications they generate through affective, behavioral and motivational determinism depend on the specificity of the activity, managerial ability and decisionmaking competence. Employees' dissatisfaction with work entails an increasing cost both at the microeconomic level, by negatively affecting the performance of companies, and at the macroeconomic level, involving high costs related to the assistance provided. Awareness by the employer that the main asset generating value is employees requires addressing the issue of their well-being as a priority, circumscribed by the function of social production. 
Potential solutions aim at leadership, communication and focus on learning and development, implementation of wellness programs that provide employees with incentives, tools, social support, confidentiality and strategies to adopt and maintain healthy behaviors that ensure involvement, commitment. The importance of approaching telework in conflict mitigation: aspirations-achievements, autonomy-control, family and professional life is defining for minimizing disadvantages and maximizing well-being at the level of individual, family and employer.

The aim of this study is to analyze the impact of telework on the well-being of employees as a sine-qua-non condition for increasing the effectiveness and efficiency of their work. Given that the well-being assessment models proposed in various studies present partial answers to the addressed issue, being sparingly treated in relation to telework, this research expands the dimensions and factors of analysis in an integrative model, which validates the partial results obtained by other authors. In the next section, a review of the literature is conducted, with the notification of the directions of interest, and the limits in the approach. The research methodology, the results of the empirical study and the discussions on them are presented below, the authors finally specifying the conclusions and future research directions.

\section{Literature review}

Defining well-being on a personal level, noticing its complexity and interconditionality, is a topic of interest in the literature. The scientific approaches regarding the well-being initially targeted the affective side, being later completed with the behavioral and motivational aspects that define the individual.

The theory of the function of social production (FPS) is an integrative approach of the theory of objectives with that of behavior, stating that people try to improve their situation by optimizing universal objectives (physical and social well-being) and instrumental objectives through which these universal objectives are achieved (stimulation and comfort for physical well-being and desired status, behavioral confirmation, and affection for social well-being) (Lindenberg, 1996; Ormel et al., 1997; 1999; Niebor et al., 2005). A general well-being assessment model, without work reference, was proposed by Ryff, taking into account six dimensions: self-acceptance ('as a central feature of mental health as well as a characteristic of self-actualization, optimal functioning, and maturity'); positive relations with others ('the importance of warm, trusting interpersonal relations'); autonomy ('qualities as self-determination, independence, and the regulation of behavior from within'); environmental mastery ('the individual's ability to choose or create environments suitable to his or her psychic conditions'); purpose in life ('clear comprehension of life's purpose, a sense of directedness, and intentionality.... goals, intentions, and a sense of direction, all of which contribute to the feeling that life is meaningful'); personal growth ('one continue to develop one's potential, to grow and expand as a person') (Ryff, 1989; Ryff and Keyes, 1995). Complementary to the affective side, other multidimensional models of well-being assessment include a wider range of aspects: COPPE I scale, targeting six dimensions: Interpersonal, Community, Occupational, Physical, Psychological, and Economic (Prilleltensky et al., 2015); another scale proposes as dimensions: career, social relationships, physical health, community, and finances (Rath and Harter, 2010). From the perspective of well-being as a whole, the International Wellbeing Group (2006) developed 
an evaluation model, Personal Well-Being Index (PWI), considering eight defining areas: standard of living, health, achieving in life, relationships, safety, community connectedness, future security, and spirituality/religion.

Trying to establish a hierarchy in the assessment of well-being, Diener, Scollon and Lucas (2009) proposed a model that includes: a first level aimed at a general assessment of a person's life; a subsequent level of assessment of subjective well-being based on four components, moderately correlated and conceptually related, which define it in more precise terms: positive affectivity (for example: joy, love, contentment), negative affectivity (for example: sadness, anger, worry), satisfaction (e.g. fulfillment, meaning, life satisfaction) and field satisfaction (e.g. work, health); at the highest level of this hierarchy is the concept of subjective well-being itself.

By contextualizing the assessment of well-being from a work perspective, a more correct understanding of how the specific characteristics of work affect the well-being of employees is ensured. A relevant model in the literature is the one developed by Warr which detected four primary dimensions (emotional well-being, aspiration, autonomy and competence) and a fifth secondary dimension (integrated functioning) which includes the four primary dimensions and reflects the person as a whole (Warr, 1987; 1994). Developing the Riff's and Warr's models, Van Horn et al. (2004) proposed and tested a multifactorial model of occupational well-being assessment, including the following dimensions: affective, cognitive, professional, social and psychosomatic dimensions. The employees' skills and competencies must be included in human capital development policies (Curea, 2017: 38). The human place and his role in the economy has radically changed ... and the creative work has become the determining factor of economic life (Robu et al., 2020:91). Another model in the field is E-Work Life (EWL) Scale that targets four determinants: Work Life Interference, Effectiveness/Productivity, Organizational Trust, Flexibility (Grant et al., 2019). Radical changes in the nature of work have induced new challenges for both employees and employers, phenomena such as job insecurity, work schedule, control at work and managerial style, being relevant variables in assessing employee well-being (Sparks et al., 2001). Increased flexibility has been associated with an improvement in wellbeing in terms of health, with a decrease in absences due to illness, as well as work commitment, mediated in this case by work-life balance (Casey and Grzywacz, 2008). Also, changes in work design through the emergence and expansion of work outside the employers' or his clients' premises have aroused the interest of academia and specialized agencies, there are studies on different aspects of well-being from this perspective. A flexible work schedule is positively associated with the well-being of employees through the increased work-life balance, autonomy and efficient communication and negatively associated with the well-being of employees through increased interruptions (Hoeven and van Zoonen, 2015). There is also a curvilinear relationship between work-related wellbeing and the widespread use of telework, as this can lead to increased work and burnout (Vander et al., 2017). In the context of the pandemic generated by SARS-CoV-2 virus, occupational stress increased as a result of the extension of telework and the imposed restrictions. Correlation analysis involves defining the dependent factor considered to be the psychological well-being of employees, assessed on the basis of environment mastery, positive growth, positive relations, self-acceptance, autonomy, purpose of life and independent explanatory factors: workload, peer, physiological factors, role ambiguity, organization climate, psychological factors and job satisfaction. Particularized at the level of employees in the information technology industry, the regression analysis revealed that

Vol. $23 \cdot$ No. $58 \cdot$ August 2021 
the ambiguity of the role, colleagues, organizational climate and job satisfaction significantly influence the psychological well-being of employees, reporting statistically significant minor differences between genders and age groups (Prasad et al., 2020). Also, in this pandemic context, four key challenges of teleworking were identified (work-home interference, ineffective communication, procrastination, and loneliness), four virtual working features that affected these challenges (social support, job autonomy, monitoring, and workload), as well as a key factor of differences at the individual level (self-discipline). The analysis showed that social support was positively correlated with lower levels of the four challenges, work autonomy was negatively linked to loneliness, workload and monitoring further interfered with the work-home relationship, and workload was positively correlated with delays. Self-discipline has been a significant moderator of many of these relationships (Bin Wang, et al., 2021).

The multiple researches carried out on a topic with a complex dimension, involving numerous individuals, each constituting systems with unique particularities, irreversible irregularities and own nonlinear feedbacks, aimed at detaching regularities, common perceptions, generalized correlations in order to increase efficiency and effectiveness of telework and individual, entrepreneurial and social well-being. The expansion of teleworking has brought new fields and aspects in research highlighting correlations considered paradoxical in the evaluation of work results, including the well-being of the individual. The paradox of connectivity proposed by Leonardi et al. (2010) and supported by Fonner and Roloff (2012), and Ten Brummelhuis et al. (2012) reveal that although communication technologies increase the quality, accuracy and ease of communication, technology-related disruptions cause stress and exhaustion, affecting the well-being of the individual. The paradox of telework (Gajendran and Harrison, 2007) is that it has both a beneficial influence on autonomy and work-life balance and a negative one on vital professional and career relationships with contradictory repercussions on the well-being of the individual. The paradox of autonomy (Michel, 2011; Mazmanian, et al., 2013; Putnam, et al., 2014) resides in the perception that the flexibility of work, although it ensures greater freedom and autonomy, implies the intensification of work and a more rigorous control.

The pandemic intensifies concerns about the study of the effects of expanding the use of telework and the constraints of work efficiency and effectiveness while ensuring the wellbeing of the individual at all levels (cognitive, emotional, social, professional and psychosomatic). The purpose of this article is to investigate and test the relationship between telework and employee well-being and the impact of the variables considered on this relationship. The introspection of the literature reveals the existence of a limited number of multidimensional models dedicated to the evaluation of the impact of telework on the well-being of employees. Also, we noticed ambiguities in the definition of the considered dimensions, their incoherent classification and the unexplained inclusion of some aspects with similar content in different categories. The contribution and originality of this article consists in conducting an empirical study beyond the sphere of occupational stress, in general, analyzing the way in which teleworking affects the well-being of employees, evaluated on various levels, in particular. 


\section{Scientific research methodology}

To analyze the relationship between telework and employee well-being level (WB) we considered seven areas of interest: professional development and competences (PDC), autonomy (AUT), job satisfaction (JS), commitment (ANG), emotional dimension (ED)), work-life balance (BWL) and organizational climate (OC), evaluated according to 52 items considered relevant in their definition.

Table no. 1. Areas of analysis

\begin{tabular}{|c|c|c|}
\hline Areas & \multicolumn{2}{|l|}{ Description } \\
\hline $\begin{array}{l}\text { Professional } \\
\text { development } \\
\text { and } \\
\text { competences }\end{array}$ & $\begin{array}{l}\text { Professional competence consists in the } \\
\text { ability to have the knowledge and } \\
\text { experience in a field of activity that } \\
\text { allows to perform certain tasks and make } \\
\text { decisions at different levels. Competence } \\
\text { is a dynamic characteristic, which } \\
\text { develops adaptively and creatively } \\
\text { through the permanent accumulation of } \\
\text { new knowledge as a result of the } \\
\text { processes of training, improvement and } \\
\text { self-development in a given context. The } \\
\text { aspiration for development is specific to } \\
\text { each individual and well-being depends } \\
\text { decisively on the possibility to } \\
\text { demonstrate and increase competence and } \\
\text { to progress on its basis. }\end{array}$ & $\begin{array}{l}\text { Telework involves specific } \\
\text { competences. Changing the work } \\
\text { condition contributes to the } \\
\text { development of additional skills and } \\
\text { competences. Telework requires the } \\
\text { ability to work individually, the } \\
\text { ability to effectively manage the } \\
\text { work schedule. } \\
\text { It is necessary to harmonize the } \\
\text { individual's aspiration for } \\
\text { development with the opportunity for } \\
\text { continuous training corresponding to } \\
\text { working conditions. }\end{array}$ \\
\hline Autonomy & $\begin{array}{l}\text { Autonomy resides in the individual's } \\
\text { ability to produce own rules, to lead own } \\
\text { process of actions and decisions. } \\
\text { Autonomy presupposes qualities such as } \\
\text { self-determination, independence, } \\
\text { intrinsic behavioral regulation, etc. There } \\
\text { are several levels of autonomy: creative } \\
\text { activities involve full autonomy; routine, } \\
\text { repetitive ones require strict regulations } \\
\text { and staging; in activities that leave a } \\
\text { space of autonomy, the decision is at the } \\
\text { level of predetermined alternative actions. }\end{array}$ & $\begin{array}{l}\text { Telework can offer a certain degree } \\
\text { of decision-making freedom } \\
\text { regarding the management of one's } \\
\text { own activity and the opportunity to } \\
\text { opt for a flexible program. } \\
\text { Employers develop procedures for } \\
\text { carrying out the activity and } \\
\text { exercise a permanent control over } \\
\text { the tasks and deadlines to a greater } \\
\text { or lesser extent depending on the } \\
\text { specifics of the work and the } \\
\text { organizational culture. }\end{array}$ \\
\hline $\begin{array}{l}\text { Work } \\
\text { satisfaction }\end{array}$ & $\begin{array}{l}\text { Satisfaction expresses a subjective state, } \\
\text { resulting from the continuous evaluation } \\
\text { of the subject on his own life and work } \\
\text { (relationships, climate, performance) } \\
\text { depending on the level of aspirations. } \\
\text { Satisfaction is adaptive to real conditions } \\
\text { and opportunities, with a minimum of } \\
\text { acceptability. Satisfaction is assessed by } \\
\text { indicators of the state of life and work } \\
\text { components, as well as by self- } \\
\text { assessment indicators depending on the } \\
\text { variation of the level of aspirations. }\end{array}$ & $\begin{array}{l}\text { The specific conditions in the case } \\
\text { of telework determine a particular } \\
\text { configuration of the components } \\
\text { regarding the work done, the } \\
\text { collaboration with the team and the } \\
\text { coordinator, the position in the } \\
\text { company, the promotion } \\
\text { opportunities, the desired personal } \\
\text { development, the relationship } \\
\text { between work and its remuneration, } \\
\text { work complexity. }\end{array}$ \\
\hline
\end{tabular}




\begin{tabular}{|c|c|c|}
\hline Areas & Description & \\
\hline Commitment & $\begin{array}{l}\text { The formal commitment consists in the } \\
\text { promise to carry out a certain activity, } \\
\text { action, in the agreed terms and to receive } \\
\text { a certain equivalent value. Real } \\
\text { commitment involves fulfilling the } \\
\text { promise in the most effective and } \\
\text { efficient way possible. Commitment } \\
\text { involves trust, a level of autonomy and } \\
\text { responsibility, loyalty, material support, } \\
\text { cognitive, communication, reciprocity for } \\
\text { the benefit of both parties. }\end{array}$ & $\begin{array}{l}\text { In telecommuting, commitment is } \\
\text { essential in carrying out the tasks } \\
\text { undertaken in good and timely } \\
\text { conditions without compromising } \\
\text { the team's results. This can be } \\
\text { manifested by the intensification of } \\
\text { work, by increasing the } \\
\text { responsibility towards the entity, by } \\
\text { a higher productivity, by a } \\
\text { permanent focus on work tasks and } \\
\text { the willingness to work overtime. }\end{array}$ \\
\hline $\begin{array}{l}\text { Emotional } \\
\text { dimmension }\end{array}$ & $\begin{array}{l}\text { Mental health involves self-acceptance, } \\
\text { positive relationships with others, } \\
\text { adapting the individual's behavior to a } \\
\text { given situation, the ability to make } \\
\text { decisions and solve problems, the ability } \\
\text { to cope with difficulties and events, the } \\
\text { tendency to self-actualization and self- } \\
\text { realization, personal growth. } \\
\text { Psychological normality and human } \\
\text { development are achieved in the context } \\
\text { of interpersonal relationships. Many } \\
\text { current instruments for measuring } \\
\text { occupational well-being include the } \\
\text { affective dimension as a determinant. }\end{array}$ & $\begin{array}{l}\text { Studies have shown an increase in } \\
\text { work intensification, in the } \\
\text { conditions of telework, which can } \\
\text { induce exhaustion, anxiety, with } \\
\text { effects enhanced by social isolation. } \\
\text { Conflicts can arise at work due to: } \\
\text { overload, coordinator, non- } \\
\text { compliance by some team } \\
\text { members. Lack of relationships and } \\
\text { emulation at work can generate } \\
\text { negative effects. }\end{array}$ \\
\hline $\begin{array}{l}\text { Work-life } \\
\text { balance }\end{array}$ & $\begin{array}{l}\text { The work-life balance implies a good } \\
\text { management of the work performance at } \\
\text { the same time as that of the positive } \\
\text { relations with the family and the society. } \\
\text { The individual is a social being and many } \\
\text { of his needs are met in the maintained } \\
\text { relational framework, in which the family } \\
\text { has an important role: psychological } \\
\text { support, love, security, status, esteem, } \\
\text { reduction of anxiety and uncertainty. }\end{array}$ & $\begin{array}{l}\text { Telework implies a certain capacity } \\
\text { for autonomous realization of } \\
\text { professional responsibilities at the } \\
\text { same time as family ones and the } \\
\text { maintenance of positive social } \\
\text { relations. Telework can ensure an } \\
\text { adequacy of the work schedule to } \\
\text { family life and other activities, } \\
\text { improving the work-non-work time } \\
\text { balance in favor of the employee. }\end{array}$ \\
\hline $\begin{array}{l}\text { Organizational } \\
\text { climate }\end{array}$ & $\begin{array}{l}\text { Social-human systems composed of } \\
\text { individuals with their own motivations } \\
\text { and specific interpersonal relationships, } \\
\text { the employing entities are structures } \\
\text { organized on performance principles. } \\
\text { Achieving their objectives involves } \\
\text { implementing a fair organizational } \\
\text { climate, collaboration, professional } \\
\text { development and trust that stimulates the } \\
\text { creative participation of its members. }\end{array}$ & $\begin{array}{l}\text { Telework requires increased } \\
\text { attention from the employer to } \\
\text { maintain a reliable and stimulating } \\
\text { connectivity, prompt interventions } \\
\text { in overcoming obstacles, certainty } \\
\text { of correctness and development } \\
\text { opportunities. }\end{array}$ \\
\hline
\end{tabular}


According to the purpose of the research, the main hypotheses we test are aimed at:

- I1: there are differences in terms of the perception of well-being in the case of employees who work in the employer's premise and those in telework;

- I2: there is a positive relationship between professional development and competences, autonomy, job satisfaction, work-life balance, organizational climate and well-being, while there is a negative relationship between the emotional dimension, commitment and well-being in the case of teleworking;

- I3: there are differences between genders regarding the appreciation of employees' well-being in the case of the telework.

The research uses in a first stage the method of sociological survey based on the questionnaire technique (Mucchielli, 1983; Cauc, 1997). The questionnaire is semistructured, comprising a part (first 11 questions) allocated to the identification of respondents in terms of field of activity, age, gender, duration of working life, professional training, position in the entity, place of work, number of days per week outside the employer's premise, longetivity in the practice of telework, average hours worked per day and IT knowledge, to allow the customization of results, as well as a part (questions 12-63) consisting of 52 closed questions, structured on defined areas of interest. The construction of the questions was done in such a way as to allow the knowledge of their opinions and their intensity, with bringing up that the closed questions, although providing a useful frame of reference for the reflection of the interviewees, exclude the possibility of expressing an opinion outside those pre-established by the researchers, with the possibility of ignoring relevant aspects. The PDC domain includes questions 14-21, AUT 22-25, JS 26-35, ANG 36-39, 50-53, ED 40-47, 59-63, BWL 48-49 and OC 12-13, 54-58. Question 64 addressed the overall assessment of well-being. Responses (very much, much, enough, little, not at all) were converted to a Linkert scale from 1 to 5, with assignment based on significance in relation to the well-being. We proceeded similarly to Van Horn et al. (2004), Ryff (1989), Hoeven and Zoonen (2015), and Grant et al. (2018). This questionnaire was randomly distributed in Romania. The representativeness of the sample was ensured in the conditions of its random selection, with the inclusion of entities from most branches of the national economy, by respecting the socio-professional, age and gender structures.

In order to test the validity of the hypotheses, the correlation analysis - in this sense the Pearson correlation coefficients were calculated, establishing the type and intensity of the correlation - and the regression analysis - to study how the analyzed endogenous variable evolves according to a change on several considered exogenous variables - were performed. The collected data were processed using the Eviews program.

\section{Results and discussion}

A total of 338 respondents completed the questionnaire, of which 110 work in the employer's premises and 228 in telework, with a share of $41.23 \%$ of men and $58.77 \%$ of women. Of the total respondents, $65.68 \%$ have higher education and $30.76 \%$ have postgraduate studies. 50 respondents are up to 25 years old, 234 are between 26 and 50 years old and 54 are over 50 years old. They work in various fields of activity: 
consulting, accounting, audit, research, public administration, banking system, trade, agriculture, construction, education, HR, IT, tourism, etc.

\subsection{Descriptive statistics}

The comparative analysis of the results of the questionnaire reveals differences in terms of the perception of well-being in the case of employees working at the employer's premises (Table no. 3) and those in telework (Table no. 2).

Table no. 2. Correlation analysis - telework

\begin{tabular}{|c|c|c|c|c|c|c|c|c|c|}
\hline Area & Mean & $\begin{array}{c}\text { Std. } \\
\text { Dev. }\end{array}$ & PDC & AUT & JS & ANG & ED & BWL & OC \\
\hline PDC & 3.97 & 0.42 & 1 & & & & & & \\
\hline AUT & 3.54 & 0.56 & $0.39^{* * *}$ & 1 & & & & & \\
\hline JS & 4.10 & 0.62 & $0.64 * * *$ & $0.48^{* * *}$ & 1 & & & & \\
\hline ANG & 3.96 & 0.63 & $0.43^{* * *}$ & $0.17 * *$ & $0.30^{* * *}$ & 1 & & & \\
\hline ED & 3.77 & 0.75 & $0.18^{* *}$ & 0.08 & $0.22^{* *}$ & $(0.01)$ & 1 & & \\
\hline BWL & 3.61 & 1.05 & $0.43^{* * *}$ & $0.34^{* * *}$ & $0.48^{* * *}$ & $0.22^{* * *}$ & $0.29 * * *$ & 1 & \\
\hline OC & 3.98 & 0.68 & $0.58^{* * *}$ & $0.45^{* * *}$ & $0.63^{* * *}$ & $0.20^{* *}$ & $0.32^{* * *}$ & $0.36^{* * *}$ & 1 \\
\hline WB & 3.82 & 0.84 & $0.41^{* * *}$ & $0.25^{* * *}$ & $0.59^{* * *}$ & $0.15^{*}$ & 0.13 & $0.32^{* * *}$ & $0.40^{* * *}$ \\
\hline
\end{tabular}

Note: $* \mathrm{p}<0.05$; $* * \mathrm{p}<0.01 ; * * * \mathrm{p}<0.001$; employees well-being level (WB), professional development and competences (PDC), autonomy (AUT), job satisfaction (JS), commitment (ANG), emotional dimension (ED), work-life balance (BWL), organizational climate (OC); standard deviation (Std.Dev.).

Table no. 3. Correlation analysis - employer's premises

\begin{tabular}{|c|c|c|c|c|c|c|c|c|c|}
\hline Area & Mean & $\begin{array}{l}\text { Std. } \\
\text { Dev. }\end{array}$ & PDC & AUT & JS & ANG & ED & BWL & OC \\
\hline PDC & 4.11 & 0.46 & 1 & & & & & & \\
\hline AUT & 3.46 & 0.61 & $0.22 *$ & 1 & & & & & \\
\hline JS & 4.15 & 0.63 & $0.57 * * *$ & $0.62 * * *$ & 1 & & & & \\
\hline ANG & 4 & 0.39 & $0.40 * * *$ & $0.39 * * *$ & $0.52 * * *$ & 1 & & & \\
\hline $\mathrm{ED}$ & 3.59 & 0.83 & $(0,02)$ & 0.01 & $(0.02)$ & $(0.19)^{*}$ & 1 & & \\
\hline BWL & 3.53 & 0.89 & $0.30 * *$ & $0.46^{* * *}$ & $0.62 * * *$ & $0.44 * * *$ & $(0.15)$ & 1 & \\
\hline $\mathrm{OC}$ & 4.18 & 0.66 & $0.45^{* * *}$ & $0.56^{* * *}$ & $0.73^{* * *}$ & $0.56^{* * *}$ & $(0.08)$ & $0.61 * * *$ & 1 \\
\hline WB & 4.09 & 1.02 & $0.34 * * *$ & $0.46^{* * *}$ & $0.59 * * *$ & $0.27 *$ & $(0.06)$ & $0.56 * * *$ & $0.61 * * *$ \\
\hline \multicolumn{10}{|c|}{$\begin{array}{l}\text { Note: } * \mathrm{p}<0.05 ; * * \mathrm{p}<0.01 ; * * * \mathrm{p}<0.001 \text {; employees well-being level (WB), professional } \\
\text { development and competences (PDC), autonomy (AUT), job satisfaction (JS), commitment } \\
\text { (ANG), emotional dimension (ED), work-life balance (BWL), organizational climate (OC); } \\
\text { standard deviation (Std.Dev.). }\end{array}$} \\
\hline
\end{tabular}

Thus, employees who work at the employer's premises have an average well-being of 4.091 , with values between a minimum of 1 and a maximum of 5 . The average value of the well-being of employees in telework is 3.816, lower than that of the first group of employees, but with minimum assigned value higher than 2 . At the level of the considered areas, the main differences regarding the deviation from the average of the answers concern the employees' commitment towards the employer, the work-life balance, with higher values in the case of employees working in telework, and well-being, with higher values in the case of employees working at the employer's premises. Consistent with the results of Solomon and Solomon (1984), the assessment of the possible implications of telework on each employee indicates that the burden on him may be greater than the benefits accrued. 


\subsection{Correlations between variables}

The correlations were examined for both samples, finding that in the case of telework, the high well-being of employees is associated with high values of all areas of interest, with a statistically significant link in the case of PDC, AUT, JS, BWL and OC, and in the case of work at the employer's premises, the well-being is negatively correlated with ED. The statistical link between PDC and AUT is more significant in the case of telework, a higher degree of autonomy being associated with higher competence. In the case of telework, there is a positive link between PDC and ED, as well as between JS and ED, while these correlations become negative in the case of work performed at the employer's premises, without being statistically significant. This can be explained by the fact that the lack of immediate support provided in the case of work at the employer's premises in case of difficulties in solving certain tasks due to the non-compliance of the competencies implies a higher emotional pressure. Job satisfaction induces greater exhaustion in the case of telework. From the point of view of the degree of association, we noticed a statistically significant strong link between well-being, professional development and competences, organizational climate and job satisfaction in the case of telework. The weakest correlations are noticed at the level of the emotional dimension. In the case of work at the employer's premises, the work-life balance has a strong link with job satisfaction and the organizational climate. Hypothesis 1 is thus validated.

\subsection{Regression analysis}

The results of estimating the regression equation are presented in table no.4. The BreuschPagan-Godfrey test revealed homoscedasticity of errors (Prob. Chi-square 0.8658). To verify the hypothesis of normality of errors, the Jarque-Bera test was performed, obtaining a probability of 0.4055 . The result of the Lagrange Multiplier test revealed a noncorrelation of the errors (Prob. Chi-square 0.09). There is no multicollinearity in the model, the VIF values of the independent variables being less than 4. (PDC: 2,138, AUT: 1,404, JS: 2,312, ANG: 1,25, ED: 1,19, BWL: 1,442 and OC: 2,027).

Table no. 4. The results of the regression analysis

\begin{tabular}{|l|c|c|c|}
\hline \multirow{2}{*}{} & \multicolumn{3}{|c|}{ Coefficient } \\
\cline { 2 - 4 } & telework & males & females \\
\hline Intercept & 0.6512 & 1.4857 & 0.3353 \\
\hline Professional development and competences & 0.1272 & 0.3513 & -0.2487 \\
\hline Autonomy & -0.0882 & -0.2404 & 0.0064 \\
\hline Job satisfaction & 0.7333 & 0.3731 & 1.0135 \\
\hline Commitment & -0.0693 & -0.1284 & 0.0316 \\
\hline Emotional dimension & -0.0307 & -0.1814 & 0.0174 \\
\hline Work-life balance & 0.0429 & 0.0206 & 0.0550 \\
\hline Organizational climate & 0.05 & 0.3390 & -0.0797 \\
\hline
\end{tabular}

R-squared is approximately $62 \%$, indicating a high correlation between well-being and independent variables included in the model estimated for the entire sample. There is a statistically significant positive relationship between well-being and job satisfaction. Professional fulfillment through the work, an efficient and pleasant collaboration with the team and the coordinator, recognition of skills and involvement in the activity with concretization in a proper position, a fair work-remuneration ratio, and the existence of opportunities to promote within the company ensure employee well-being. Our results are similar to those obtained by Bowling et al. (2010), Cannas et al. (2019) and in agreement 
with those of Van Horn et al. (2004), who found that the affective dimension, which includes job satisfaction, is the central dimension of the analysis.

Professional development and competences determine an improvement in well-being. A negative relationship was observed between autonomy and well-being. The paradox of autonomy shows that a high level of it induces the intensification of work and leads to exhaustion and degradation of well-being. In the conditions of a great freedom of decision in the management of one's own activity, of the opportunity to opt to a large extent for a flexible program, this situation is explained by the perception of exercising to a small extent a permanent control over the tasks and deadlines. Thus, the lack of a permanent control generates discomfort at the level of the sample, the need for control, of a coordination of the actions being associated with the desire of certainty and security of the individual. Consistent with the results of Gallie's research (2007), control over work is important in determining the quality of professional life, stimulating creativity and developing skills. We found an association between labor control and greater job satisfaction, similar to Thompson and Prottas (2006). People who have worked successfully at home have proven to be highly self-motivated and self-disciplined, a conclusion also found in Olson's (1983) studies. Employee engagement generates a higher frequency of positive affects, embodied in work efficiency, employee retention, creativity and, ultimately, business outcomes (Harter et al., 2003). The flexibility of the program provided by telework induces a higher commitment materialized in assuming an increased responsibility towards the entity, work intensification, involvement in work activities outside of formal hours, and a higher labor productivity, which adversely affects the perception of well-being.

There is a negative relationship between the emotional dimension and the well-being of employees. Exhaustion induced by constant access to work and the additional demands, stress on the quality and completion of tasks, meeting deadlines and the frequent need to correct, tensions created by various conflicts arising from overloading or non-compliance with the requirements and lack of relationships and workplace emulation generated by telework negatively affect the well-being of employees. We also found that the nonseparation of work-life space reduces the recovery effect provided by home, similar to Fonner and Roloff (2010), Grant et al. (2013). Psychological detachment from work outside working hours has positive affects especially in the case of high commitment, result in agreement with that of Sonnentag et al. (2008). Like Gajendran and Harisson (2007), we found that teleworking had little effect on autonomy. Also, high-intensity telework (more than 2.5 days a week) accentuated the beneficial effects on labor-family conflicts, but affected relationships with co-workers. Unlike the results obtained by them, we noticed that teleworking accentuated labor disputes and slightly damaged job satisfaction. The flexibility of the program ensures the adequacy of the program to family life and other activities, causing satisfaction regarding the work-non-work time balance, presenting a positive connection with the well-being of employees. Well-being has a positive relationship with the organizational climate created by the employer by providing the necessary infrastructure to carry out the activity, settlement of expenses generated by telework, ease of communication with the team manager/coordinator, as well as colleagues, trust in timely tasks, support if employees do not perform. The second hypothesis is confirmed, there is a positive relationship between professional development and competences, job satisfaction, work-life balance, organizational climate and well-being and a negative relationship between the emotional dimension, commitment and well-being. 
The inclusion of the gender dimension in the analysis of the links between the well-being of employees and the considered independent variables reveals a difference in perception between women and men. In the case of women, there is a negative link between wellbeing and professional development, as well as between well-being and the organizational climate, while for men they are positive. On the other hand, there are positive connections in the perception of women in the relations autonomy - well-being (due to the different perception especially regarding the need for procedures and control), commitment - wellbeing, emotional dimension - well-being; in the opinion of men they are negative. Psychic factors and behavioral habits, in a less restrictive climate, favor the predisposition of women to assume responsibilities with more openness and involvement, while men prefer the rigor of a delimited framework of action. Hypothesis 3 is validated; the differences in perception reside fundamentally from the habit of women to carry out their activities in their own home and of men outside it, with influences in the appreciation of well-being at the level of employees in the case of the telework.

\section{Conclusions}

The approach of the well-being of the employees as a distinct phenomenon, with specific defining characteristics, constitutes a problem of interest, amplified in the conditions of the current crisis generated by SARS-CoV-2 virus. The proposed multidimensional model completes the tools in the specialized literature allowing a viable measurement of the wellbeing of the employees who carry out their activity in telework. From the perspective of the theory of social production function, this model allows the evaluation of the universal objective of well-being in an integrative approach that considers as instrumental objectives PDC, AUT, JS, ANG, ED, BWL. The pertinence of this conceptual model is ensured by the convergence with other models in the field - which, although not aimed at this relationship, confirms the advantages and challenges of telework by association with certain arias - as well as the results obtained by sociological analysis. The model targets a variety of organizational contexts, including the possibility of the option for a mobile location, for a flexible schedule in terms of number of hours or work interval. Contextualizing the assessment of well-being by relating it to the workplace ensures a higher degree of relevance. The results of the empirical study show that there are differences in the perception of well-being in the case of employees working in the employer's premises and those in telework, as well as between women and men. There is a positive relationship between professional development and competences, job satisfaction, work-life balance, organizational climate and well-being, while between autonomy, emotional dimension, commitment and well-being there is a negative relationship in the case of telework. These results are consistent with our expectations and those of previous research. In terms of practical implications, the model provides human resources professionals and employers with a useful tool for assessing the well-being of employees in order to improve it through appropriate policies, training, creating an organizational climate that strengthens constructive behavior, performance, with synergistic effects at the level of individual, entities and society. The exodus of staff from employers' premises as a result of the COVID-19 pandemic affects the organizational culture, except in cases where leaders get involved and support it (Howard-Grenville, 2020). For academia and specialists in the field, this model can be integrated into the ongoing research in the field of telework. The main limitation of the research is the dimension of the sample, which does not affect the results, 
given the subjective nature of the evaluations. Sample extend and other validity tests may confirm the relevance of the model. Future research will be oriented towards the development of the model by deepening the competences, the emotional aspects in the context of a certain organizational culture, using the analysis of confirmatory factor analysis.

\section{References}

Alfonso, S.P. and Andrés, A.S.P., 2000. Well-being at work: a cross-national analysis of the levels and determinants of job satisfaction. The Journal of Socio-Economics, 29(6), pp.517-538.

Bin, W., Yukun, L., and Sharon, K.P., 2021. Achieving Effective Remote Working During the COVID-19 Pandemic: A Work Design Perspective. Applied Psychology, 70(1), pp.16-59.

Bowling, N.A., Eschleman, K.J. and Wang, Q., 2010. A meta-analytic examination of the relationship between job satisfaction and subjective well-being. Journal of Occupational and Organizational Psychology, 83(4), pp.915-934.

Cannas, M., Sergi, B., and Mentel, U., 2019. Job satisfaction and subjective well-being in Europe, Economics \& Sociology, 12(4), pp.183-196.

Casey, P.R. and Grzywacz, J.G., 2008. Employee health and well-being: The role of flexibility and work-family balance. The Psychologist-Manager Journal, 11(1), pp.31-47.

Cauc, I., Manu, B., Părlea, D. and Goran. L., 2007. Metodologia cercetării sociologice. Metode şi tehnici de cercetare. București: Editura Fundației România de Mâine.

Charalampous, M., Grant, C.A., Tramontano, C. and Michailidis, E., 2018. Systematically reviewing remote e-workers' well-being at work: a multidimensional approach. European Journal of Work and Organizational Psychology, pp.1-23.

Curea, S.C., 2017. Impactul capitalului uman asupra creşterii economice. București: Editura Economică.

Diener, E., Emmons, R.A. and Griffin R.J.L.S., 1985. The Satisfaction With Life Scale. Journal of Personality Assessment, 49(1), pp 71-75.

Diener, E., Scollon, C. and Lucas, R., 2009. The evolving concept of subjective well-being: Themultifaceted nature of happiness. Social Indicators Research Series, 39, pp.67-100.

Felstead, A. and Henseke, G., 2017. Assessing the growth of remote working and its consequences for effort, well-being and work-life balance. New Technology, Work and Employment, 32(3), pp.195-212.

Fonner, K.L. and Roloff, M.E., 2010. Why teleworkers are more satisfied with their jobs than are office-based workers: When less contact is beneficial. Journal of Applied Communication Research, 38(4), pp.336-361.

Fonner, K.L. and Roloff, M.E., 2012. Testing the Connectivity Paradox: Linking Teleworkers' Communication Media Use to Social Presence, Stress from Interruptions, and Organizational Identification. Communication Monographs, 79(2), pp.205-231.

Gajendran, R.S. and Harrison, D.A., 2007. The good, the bad, and the unknown about telecommuting: Meta-analysis of psychological mediators and individual consequences. Journal of Applied Psychology, 92(6), pp.1524-1541. 
Gallie, D., 2007. Employment Regimes and the Quality of Work. Oxford: Oxford University Press.

Grant, C.A., Wallace, L.M. and Spurgeon, P.C., 2013. An exploration of the psychological factors affecting remote e-worker's job effectiveness, well-being and work-life balance. Employee Relations, 35(5), pp.527-546.

Grant, C.A., Wallace, L.M., Spurgeon, P.C., Tramontano, C. and Charalampous, M., 2019. Construction and initial validation of the E-Work Life Scale to measure remote e-working. Employee Relations, 41(1), pp.16-33.

Harter, J.K., Schmidt, F.L. and Keyes, C.L.M., 2003. Well-being in the workplace and its relationship to business outcomes: A review of the Gallup studies. In C. L. M. Keyes \& J. Haidt, eds. 2003. Flourishing: Positive psychology and the life well-lived. Washington DC: American Psychological Association.

Hoeven, C.L. and Zoonen, W., 2015. Flexible work designs and employee well-being: examining the effects of resources and demands. New Technology, Work and Employment, 30(3), pp 237-255.

Howard-Grenville, J., 2020. How to sustain your organization's culture when everyone is remote. MIT Sloan Management Review: MIT's journal of management research and ideas, 62(1). https://doi.org/10.17863/CAM.60133.

Keyes, C.L.M., Shmotkin, D. and Ryff, C.D., 2002. Optimizing well-being: The empirical encounter of two traditions. Journal of Personality and Social Psychology, 82(6), pp.1007-1022.

Leonardi, P.M., Treem, J.W. and Jackson, M.H., 2010. The Connectivity Paradox: Using Technology to Both Decrease and Increase Perceptions of Distance in Distributed Work Arrangements. Journal of Applied Communication Research, 38(1), pp.85-105.

Lieke, L.B., Arnold, B.B. and Liesbeth, K., 2012. Do new ways of working foster work engagement?. Psicothema, 24(1), pp.113-120.

Lindenberg, S., 1996. Continuities in the theory of social production functions. In S.Lindenberg and H.B.G. Ganzeboom, eds. 1996. Verklarende sociologie: opstellenvoor Reinhard Wippler. Amsterdam: Thesis Publishers. Ch.10.

Mazmanian, M., Orlikowski, W.J. and Yates, J., 2013. The Autonomy Paradox: The Implications of Mobile Email Devices for Knowledge Professionals. Organization Science, 24(5), pp.1337-1357.

Michel, A.A., 2011. Transcending Socialization: A Nine-Year Ethnography of the Body's Role in Organizational Control and Knowledge Worker Transformation. Administrative Science Quarterly, 56(3), pp.325-368.

Mucchielli, R., 1983. Le questionnaire dans l'enquête psycho-sociale: connaissance du problème, applications pratiques. Montrouge: Esf Editeur.

Naisbit, J., 1989. Megatendinţe. Bucureşti: Editura Politică.

Nieboer, A., Lindenberg, S., Boomsma, A. and Van Bruggen, A.C., 2005. Dimensions of well-being and their measurement-The SPF-IL scale. Social Indicators Research, 73, pp.313-353.

Olson, M.H., 1983. Remote office work: changing work paterns in space and time. Comunications of the ACM, 26(3), pp.1-56. 
Ormel, J., Lindenberg, S., Steverink, N. and Vonkorff, M., 1997. Quality of life and social production functions: A framework for understanding health effects. Social Science \& Medicine, 45 (7), pp.1051-1063.

Ormel, J., Lindenberg, S., Steverink, N. and Verbrugge, L., 1999. Subjective Well-Being and Social Production Functions. Social Indicators Research, 46(1), pp.61-90.

Prasad, K.D.V., Rajesh, W. V. and Mruthyanjaya, R.M., 2020. Effect of occupational stress and remote working on psychological well-being of employees: an empirical analysis during COVID-19 pandemic concerning information technology industry in Hyderabad. Indian Journal of Commerce \& Management Studies , 11(2), pp.01-13.

Prilleltensky, I., Dietz, S., Prilleltensky, O., Myers, N.D., Rubenstein, C.L., Jin, Y. and McMahon, A., 2015. Assessing multidimensional well-being: development and validation of the i coppe scale. Journal of Community Psychology, 43(2), pp.199-226.

Putnam, L.L., Myers, K.K. and Gailliard, B.M., 2013. Examining the tensions in workplace flexibility and exploring options for new directions. Human Relations, 67(4), pp.413-440.

Robu, V., Anica-Popa, A. and Curea, S.C., 2020. Analiză economico-financiară. București: Editura A.S.E.

Ryff, C.D., 1989. Happiness is everything, or is it? Explorations on the meaning of psychological well-being. Journal of Personality and Social Psychology, 57(6), pp.1069-1081.

Ryff, C.D. and Keyes, C.L.M., 1995. The structure of psychological well-being revisited. Journal of Personality and Social Psychology, 69(4), pp.719-727.

Salomon, I. and Salomon, M., 1984. Telecommuting: The employee's perspective. Technological Forecasting and Social Change, 25(1), pp.15-28.

Sonnentag, S., Mojza, E.J., Binnewies, C. and Scholl, A., 2008. Being engaged at work and detached at home: A week-level study on work engagement, psychological detachment, and affect. Work \& Stress, 22(3), pp.257-276.

Sparks, K., Faragher, B. and Cooper, C.L., 2001. Well-being and occupational health in the 21st century workplace. Journal of Occupational and Organizational Psychology, 74(4), pp.489-50.

Thompson, C.A. and Prottas, D.J., 2006. Relationships among organizational family support, job autonomy, perceived control, and employee well-being. Journal of Occupational Health Psychology, 11(1), pp.100-118.

Tov, W. and David, C., 2012. The Importance of Employee Well-being. Business Times, pp.14.

Van Horn, J.E., Taris, T.W., Schaufeli, W.B. and Schreurs, P.J.G., 2004. The structure of occupational well-being: A study among Dutch teachers. Journal of Occupational and Organizational Psychology, pp 365-375.

Vander, E.T., Verhoogen, R., Sercu, M., Van den Broeck, A., Baillien, E. and Godderis, L., 2017. Not Extent of Telecommuting, But Job Characteristics as Proximal Predictors of Work-Related Well-Being. Journal of Occupational and Environmental Medicine, 59(10), pp.e180-e186(7). 